\title{
PERLINDUNGAN HUKUM TERHADAP JURNALIS WARGA YANG BERBASIS TEKNOLOGI INFORMASI
}

\author{
Emi Puasa Handayani \\ Fakultas Hukum Universitas Islam Kadiri (UNISKA) \\ Jalan Sersan Suharmaji No.38 Kediri, Jawa Timur, Indonesia
}

\begin{abstract}
Along with the development of technology with the invention of the internet, the speed information cannot be blocked. Black list that occurredin the print era no longer applied when the era of information technology. The problem is, when it appears journalists from citizens namely the ordinary citizens who write news or facts in blogs or personal website, then it is exposed to public whether there is any protection for the journalist. These are problems that were examined in the article titled Legal Protection Against Journalists Citizen-Based Information Technology. The results of this study can be concluded that now everyone can write and submit his writings to the audience with ease. Currently in Indonesia citizen journalism grown fairly well. This is evidenced by the number of blogs that exist in Indonesia and made by the people of Indonesia. The existence of the blog has signaled that citizen journalism is a phenomenon that is in demand and will continue to grow in the community. The nature of citizen journalism that allows all internet users can enter information that he had through the Internet, can cause a state of some kind of 'abuse of power' by the accessor. The absence of clear boundaries about what should and should not be put on the internet has made sites and blogs contain information that should not be. Therefore it needs to be a rule in the special form of legislation on the protection of citizen journalists.
\end{abstract}

Keywords : Legal Protection, Citizen Journalism,Technology Information 


\begin{abstract}
ABSTRAK
Seiring dengan perkembangan tekhnologi dengan ditemukannya internet, maka kecepatan informasi tidak bisa dibendung. Blakc list yang terjadi dalam era cetak tidak lagi berlaku saat era tehnologi informasi. Yang menjadi persoalan adalah, ketika muncul jurnalis warga, yakni warga biasa yang menulis berita atau fakta ke dalam blog atau website pribadi, kemudian ter ekpos dan menjadi milik publik, adakah perlindungan untuk para pewarta tersebut. Inilah persoalan yang dikaji dalam tulisan yang berjudul Perlindungan Hukum Terhadap Jurnalis Warga Yang Berbasis Tehnologi Informasi. Hasil kajian ini bisa di simpulkan bahwa setiap orang kini bisa menulis dan menyampaikan tulisannya kepada khalayak dengan mudah. Saat ini di Indonesia citizen journalism berkembang dengan cukup baik. Hal ini dibuktikan dengan banyaknya blog yang ada di Indonesia dan dibuat oleh masyarakat Indonesia. Keberadaan blog tersebut telah menandakan citizen journalism merupakan satu fenomena yang diminati dan akan terus berkembang dalam masyarakat. Sifat citizen journalism yang memungkinkan semua pengakses internet dapat memasukkan informasi yang ia miliki melalui internet, dapat menyebabkan keadaan semacam 'penyalahgunaan wewenang' oleh pengakses. Tidak adanya batasan yang jelas mengenai apa yang boleh dan tidak boleh dimasukkan dalam internet telah membuat situs dan blog memuat informasi yang tidak seharusnya. Sebab itulah maka perlu aturan dalam bentuk perundangundangan kusus tentang perlindungan jurnalis warga.
\end{abstract}

Kata Kunci : Perlindungan Hukum, Junalis Warga, Tekhnologi Informasi 


\section{A. PENDAHULUAN}

\section{Latar Belakang Masalah}

Citizen journalism, selanjutnya disebut CJ, akhir-akhir ini menjadi perbincangan para pakar media internasional karena di beberapa negara ternyata memiliki kemampuan menjadi media alternatif bagi warga, bahkan pada beberapa kasus menyaingi eksistensi jurnalisme profesional dalam hal ini televisi, surat kabar dan radio. Sebut saja blog ohmynews.com di Korea Selatan yang efektif menyuarakan aspirasi warganya, Stomp.sg milik warga Singapura dan malaysiakini.com milik warga Malaysia yang disebut-sebut sebagai media oposisi pemerintah.

Pada perkembangannya kemunculan CJ mendapatkan penolakan dari mainstream media yang merasa citizen jurnalis bukan profesional yang bisa melakukan reportase layaknya jurnalis profesional. Misalnya saja The New York Times yang mempertanyakan keakuratan dan objektifitas hasil peliputan CJ. Tradisional jurnalist juga mengaku skeptis dan menganggap CJ tidak dapat melakukan peliputan dengan baik karena hanya jurnalist terlatih yang mengetahui etika media saat melakukan peliputan.

Meski mendapat kritikan pedas semacam ini, namun CJ terus berkembang, bahkan pada beberapa peristiwa penting di dunia CJ menjadi pihak nomer 1 yang memberikan informasi kepada masyarakat. Misalnya saja saat stunami terbesar di Samudera Hindia, video dan informasi penting justru bersumber dari blog yang dimiliki warga. Blog-blog pribadi warga juga menjadisaksi peristiwa besar lain seperti perang irak.

Perkembangan CJ sendiri juga sampai di Indonesia, dimana saat ini jika tidak bisa dibilang populer - nama CJ versi online mulai bernunculan. Misalnya saja blog wikiku.com, kabarindonesia.com, indonesiasatu.net dan mediabersama.com. Sayangnya keberadaan mereka masih kurang mendapat apresiasi warga sendiri. Padahal bloger di Indonesia pada dasarnya memberikan kontribusi besar bagi masa reformasi di Indonesia 
tahun 1998, dimana saat itu para bloger lah yang melaporkan indikasi KKN di keluarga cendana.

Semenara saat tsunami di Aceh, CJ dengan blogger dan gambar video amatir yang diupload di youtube, berhasil memberikan data multimedia yang ternyata membantu menggalang dana besar dari seluruh penjuru Indonesia bahkan dunia bagi para korban di Aceh.

Dalam sebuah seminar tentang berkembangan teknologi informasi yang diikuti oleh penulis, pembicara dari Malaysia mengatakan bahwa citizen online journalism di Malaysia berkembang karena negara ini tidak memiliki kebebasan pers. Jadi dia sendiri mengatakan bahwa pada dasarnya negara seperti Indonesia tidak memerlukan CJ karena pers konvensional sudah memberikan informasi yang dibutuhkan oleh masyarakat.

Pernyataan itu bisa dibenarkan, namun meski demikian, seharusnya Indonesia tidak menutup diri untuk CJ kerena di negara asal CJ yaitu Amerika yang juga telah memiliki kebebasan pers saja, kehidupan media sudahdipengaruhi oleh media online, termasuk informasi yang disediakan oleh para blogger dalam bentuk CJ.

Di Indonesia sendiri, seiring dengan meningkatnya penggunaan internet di Indonesia dan tentu saja pengaruh dari trend media di era digital, CJ mulai dikenal. Namun sayangnya, saat ini belum ada perhatian dan pendataan yang resmi tentang gambaran CJ yang ada di Indonesia. Sebelum melakukan penelitian, peneliti melihat ada 3 jenis website di Indonesia yang membuka forum untuk Citizen Journalism yaitu website mainstream media, portal (biasanya berita dan hiburan) dan situs khusus CJ.

Masih banyak masyarakat Indonesia yang belum paham tentang media baru yang di sebagian negara sudah menjadi channe demokrasi yang efektif bahkan melebihi fungsi yang dimiliki mainstream media. Pengenalan CJ di Indonesia justru berawal bukan dari website khusus CJ, namun justru buntut dari perkembangan online journalism gagasan 
mainstream media yang di era TI ini beramai-ramai membuat versi online. Sebut saja situs kompas.com milik harian Kompas yang memiliki dua situs CJ dengan brand extension masing-masing, yaitu Kompasiana dan KoKi. Dalam situsnya www.kompasiana.com_dijelaskan bahwa kompasiana merupakan forum diskusi dan ruang kuliah berisi gagasan bernas dan mencerahkan, demokratis, konstruktif, dan bertanggung jawab. Pembaca atau pengunjung diajak urun rembug dengan mengomentari setiap artikel yang masuk. Sementara, "Komunitas kompas" atau Koki dengan alamat web http://community.kompas.com berisitulisan masyarakat, sedangkan Kompasiana adalah semacam blog jurnalist yang berisi tulisan dari para jurnalist Kompas.

Contoh lain surat kabar daerah Suara Merdeka juga tidak mau ketinggalan dengan menyadiakan beberapa halaman di webnya untuk "suara warga" dengan alamat web http://citizennews.suaramerdeka.com. Hal yang berbeda dibuat oleh Media Indonesia yang menyediakan fasilitas weblog kepada pembacanya di alamat http://blog.mediaindonesia.com. Disini warga bisa membuat blog dan menulis tentang apa saja, dengan isi tanggung jawab pemilik blog.

Sementara situ khusus CJ yang saat ini terdeteksi aktif melakukan kegiatan diantaranya www.wikimu.com, www.kabarindonesia.com, www.penyingkul.com, www.sumbawanews.com. Sementara yang ada di portal satu-satunya yang sementara ditemukan peneliti adalah www.inilah.com yang merupakan salah satu portal yang paling banyak dikunjungi di Indonesia selain www.detik.com dan www.okezone.com.

Selain di media cetak dan situs internet, istilah CJ di Indonesia juga mucul dalam program berita televisi I-witness yang ditayangkan Metro TV, dimana didalamnya berisi berita video amateur yang diambil warga dan diolah kembali oleh tim pemberitaan Metro TV. Program sejenis ini, kabarnya juga akan segera dibuat oleh televisi berita terbaru di Indonesia yaitu TV One. 
Sementara dari media radio, radio Elshinta telah menerapkan citizen jounalism sejak tahun 2000 dan saat ini sudah memiliki 100.000 netizen. CJ di radio Elshinta sendiri bentuknya adalah laporan langsung dari warga yang menjadi saksi mata suatu kejadian. Mereka biasanya ditelpon oleh Elshinta untuk kemudian on-air melaporkan kejadian di lapangan.

Perkembangan citizen online journalism menggembirakan karena memungkinkan masyarakat indonesia memiliki akses untuk menjadi subyek dalam pemberitaan. Masyarakat juga mendapat kesempatan menyuarakan aspirasinya karena memiliki space di online media. Hal ini penting mengingat media massa - meski berada di dalam lingkup negara yang memiliki kebebasan pers - tetap memiliki keterbatasan misalnya kecondongan pada berbagai kepentingan terutama kapital dan politis. Dengan demikian maka penting untuk menyambut CJ yang diharapkan akan memberikan warna tersendiri yang lebih independen dan jujur di dunia media di Indonesia.

Perlu menjadi perhatian peneliti disini adalah masih minimnya sumber informasi tentang CJ di Indonesia, mengingat CJ masih hal yang baru. Peneliti juga melihat CJ di Indonesia memiliki beberapa keunikan dan perbedaan dengan konsep CJ yang terjadi di negara asalnya. Dari dasar itulah, peneliti tertarik untuk melakukan study kasus tentang perkembangan CJ di Indonesia.

Jurnalisme warga yang sering diartikan sebagai berita yang dikirim untuk media oleh warga biasa tanpa latar belakang jurnalisme merupakan konsep yang berbeda dengan public journalism/jurnalisme publik. Jurnalisme publik, yang sering dipakai bergantian dengan civic journalism, pada dasarnya dikembangkan oleh wartawan profesional menyikapi meningkatnya ketidakpercayaan publik terhadap media dan kesinisan publik terhadap politik di Amerika Serikat sekitar tahun 1988. Kritik pedas terhadap standar dan arogansi media membawa media berpikir tentang fungsi dan tanggung jawabnya terhadap masyarakat dan bagaimana wartawan lebih responsif dengan masalah yang menjadi perhatian 
masyarakat, inilah yang dikenal sebagai jurnalisme publik. Civic journalism (digunakan secara bergantian dengan jurnalisme publik) mencoba mendefinisi ulang nilai berita, mempertanyakan nilai objektivitas dan imparsialitas, mendorong keterlibatan wartawan lebih besar sebagai peserta aktif dalam masyarakat, dan menginginkan praktik jurnalisme yang mencerminkan keragaman kultural di masyarakat Amerika.

Kemunculan gerakan civic journalism merupakan reaksi terhadap jurnalisme konvensional yang menghiraukan kewajiban untuk mewakili kepentingan pembacanya, dan dalam tingkat tertentu menjadi alat mengeruk keuntungan semata. Namun civic journalism yang dijalankan oleh mass media tidak mampu bertahan lama lantaran program beritanya memerlukan dana yang besar. Tahun 2003 pelopor civic journalism the Pew Center of Civic Journalism membubarkan diri.

Civic journalism ini membuka pintu bagi tumbuhnya jurnalisme warga dimana warga yang mempunyai berita, dan foto dapat menyampaikannya langsung melalui blog atau ke beberapa mainstream media yang sudah Selama ini jurnalisme warga ini lebih dikenal dan populer melalui medium internet. Outing (2005) membuat kategori jurnalisme warga yang ada di situs internet sebagai berikut:

1. Situs internet mengundang komentar dari masyarakat. Pembaca diperbolehkan untuk bereaksi, mengkritik, memuji atau memberi tambahan ke berita yang ditulis oleh wartawan professional. Berita tambahan dan foto dari pembaca yang disandingkan dengan berita utama dari wartawan professional juga bisa dipakai.

2. Liputan dengan sumber terbuka dimana reporter professional bekerja sama dengan pembaca yang tahu tentang suatu masalah. Berita tetap ditulis oleh reporter professional.

3. Rumah blog. Situs internet yang mengundang pembaca untuk menampilkan blognya. 
4. Situs internet publik teredit dan tidak teredit dengan berita dari publik.

5. Situs "reporter pro+warga" berita dari reporter profesional diperlakukan sama dengan berita dari publik. Ohmynews masuk dalam kategori ini.

6. Wiki-jurnalisme yang menempatkanpembaca sebagai editor.

Blog dan situs web interaktif seperti situs jurnalisme warga terpopuler Ohmynews (www.ohmynews.com) di Korea Selatan yang berdiri tahun 2000 dan kini punya 40.000 reporter warga dan 70 wartawan profesional adalah beberapa bentuk jurnalisme warga di internet. Jurnalisme warga Ohmynews berkembang pesat karena masyarakat Korea Selatan memerlukan media alternatif di tengah kuatnya kontrol tidak langsung dari pemerintah terhadap media meski kebebasan pers sudah ada.

Selain itu, masyarakat Korea Selatan juga sudah akrab dengan internet yaitu sekitar 30 juta atau 2/3 penduduknya terhubungkan dengan internet berkecepatan tinggi seperti yang tercantum dalam The National Internet Development Agency of Korea -NIDA (2004). Di Indonesia, jurnalisme warga ini justru berawal dari stasiun radio Elshinta sejak tahun 2000, dan hingga kini Elshinta punya 100.000 reporter warga. Namun, mainstream media lain seperti stasiun $\mathrm{TV}$, media cetak, website di Indonesia terlihat masih enggan untuk mengadopsi jurnalisme warga dalam praktik jurnalisme mereka karena takut kehilangan kredibilitas, reputasi dan problem etika jurnalistik.

\section{Rumusan Masalah}

Bagaimana perlindungan hukum terhadap jurnalis warga yang berbasis teknologi informasi

\section{Tujuan Penelitian}

Untuk mengkaji secara mendalam perlindungan hukum terhadap jurnalis warga yang berbasis teknologi informasi. 


\section{B. PEMBAHASAN}

\section{Jurnalisme Warga Berbasis Teknologi Informasi}

Berbicara tentang CJ tidak bisa lepas dari konsep yang memayunginya yaitu Online Journalism. Mark Deuze, profesor dari University of Amsterdam dan ahli media digital mengkonstruksi empat tipe online journalism berdasarkan keterkaitan dengan editorial maistream media dan konektivitas pada publik di satu sisi dan unmoderated dan moderated communication disisi lainnya. Keempatnya digambarkan dengan bagan berikut :

a. Mainstream News Sites : web yang dimiliki media konvensional yang biasanya hanya berupa versi online dari media konvesional. Di Indonesia bisa dibilang saat ini telah dimiliki oleh konvesional media, contohnya kompas.com, liputan6.com, mediaindonesia.com, suaramerdeka.com, dll.

b. Index and Category Sites : tipe online media ini digunakan untuk menghubungkan pembaca dengan news site yang ada di internet. Contohnya adalah yahoo!, google.com, AOL. Kategori ini melibatkan editor yang memonitor breaking news, forum diskusi, dan monitor chat.

c. Meta and Comment Sites : Tipe ini disebut journalism tentang journalism, yaitu berupa situs informasi, data dan hasil penelitian yang berkaitan dengan journalisme dan media. Contohnya poynter.org dan weblog yang dioperasikan oleh para pengkritisi media bisa masuk dalam kategori ini.

d. Share and Disscusion Sites : Tipe terakhir ini berisi tentang situs yang fokus pada kepentingan publik, berupa komunikasi partisipator yang minim pengeditan dan moderator. Situs berisi posting berita, informasi dan analisis yang dibuat pemilik situs. Contohnya adalah Slashdost, Kuro5shin dam berbagai macam weblog group. 
Ke empat tipe ini CJ masuk dalam kategori share dan disscussion sites. Slashdot dan Kuro5shin masuk dalam kategoti CJ menurut J.D. Lasica, dalam Online Journalism Review (2003) yaitu kategori media kolaboratif.

Ada beberapa istilah yang dikaitkan dengan konsep CJ (di Indonesia biasa disebut jurnalisme warga) diantaranya public journalism, civic journalism, advocacy journalism, citizens media participatory journalism, participatory media, open source reporting, distributed journalism hingga grassroot journalism.

Shayne Bowman \& Chris Willis mendefinisikan citizen journalism sebagai the act of citizens playing an active role in the process of collecting, reporting, analyzing, and disseminating news and information"." Ini artinya warga memiliki hak untuk menjadi pencari, pemproses dan penganalisa berita untuk kemudian dilaporkan kepada masyarakat luas melalui media.

Sementara Wood and Smith mendefinisikan netizens (sebutan untuk citizen journalist sebagai sekelompok warga yang aktif memberikan kontribusi berita seiring dengan perkembangan internet. Menurutnya netizen harus memahami nilai-nilai kerja kolektif dan aspek-aspek yang harus dimiliki dalam menjalankan proses komunikasi publik.

$\mathrm{CJ}$, meski berangkat dari berbagai konsep jurnalisme di atas namun memiliki keunikan khusus yang tidak dimiliki konsep lain dimana CJ berada sama posisi dengan jurnalisme profesional termasuk tugasnya yaitu meliput, menganalisa dan menyiarkan berita yang dibuatnya.

Moch Kurniawan membeberkan bagaimana konsep CJ berawal. Pertama lahir, jurnalisme publik yang pada dasarnya dikembangkan oleh wartawan profesional untuk menyikapi meningkatnya ketidakpercayaan publik terhadap media dan kesinisan publik terhadap politik di Amerika Serikat sekitar tahun 1988. Saat itu, kritik pedas terhadap standar dan arogansi media membawa media berpikir tentang fungsi dan tanggung jawabnya terhadap masyarakat dan bagaimana wartawan lebih responsif 
dengan masalah yang menjadi perhatian masyarakat, inilah yang dikenal sebagai jurnalisme publik.

Civic journalism mencoba mendefinisi ulang nilai berita, mempertanyakan nilai objektivitas dan imparsialitas, mendorong keterlibatan wartawan lebih besar sebagai peserta aktif dalam masyarakat, dan menginginkan praktik jurnalisme yang mencerminkan keragaman kultural di masyarakat Amerika.

Kemunculan gerakan civic journalism merupakan reaksi terhadap jurnalisme konvensional yang menghiraukan kewajiban untuk mewakili kepentingan pembacanya, dan dalam tingkat tertentu menjadi alat mengeruk keuntungan semata. Namun civic journalism yang dijalankan oleh mass media tidak mampu bertahan lama lantaran program beritanya memerlukan dana yang besar. Tahun 2003 pelopor civic journalism the Pew Center of Civic Journalism membubarkan diri. Civic journalism ini membuka pintu bagi tumbuhnya CJ dimana warga yang mempunyai berita, dan foto dapat menyampaikannya langsung melalui blog atau ke beberapa mainstream media yang sudah mengakomodasi misalnya situs $B B C$ (www.bbc.co.uk), CNN (www.cnn.com), dll. Dan dari sinilah CJ lahir dan berkembang hingga saat ini.

J.D. Lasica, dalam Online Journalism Review, mengategorikan media citizen journalism ke dalam enam tipe:

a. Audience participation (seperti komenter user yang diattach pada kisah-kisah berita, blog-blog pribadi, foto, atau video footage yang diambil dari handycam pribadi, atau berita lokal yang ditulis oleh anggota komunitas)

b. Situs web berita atau informasi independen (Consumer Reports, Drudge Report)

c. Situs berita partisipatoris murni (OhmyNews)

d. Situs media kolaboratif (Slashdot, Kuro5hin)

e. Bentuk lain dari media 'tipis' (mailing list, newsletter e-mail) 
f. Situs penyiaran pribadi (situs penyiaran video, seperti KenRadio)

Sementara itu dua tahun kemudian seorang ahli media yang sering menulis di poynter.org, Stive Outing memilah citizen journalism ke dalam 11 kategori:

a. Membuka ruang untuk komentar publik, dimana pembaca bisa bereaksi, memuji, mengkritik, atau menambahkan bahan tulisan jurnalis professional. Ini mungkin yang kita kenal sebagai ruang "surat pembaca" di media konvensional.

b. Menambahkan pendapat masyarakat sebagai bagian dari artikel yang ditulis jurnalis professional. Biasanya ada kontribusi pendapat dari luar jurnalis, dimana foto kontributor akan ikut diterbitkan. Ini juga yang biasa kita jumpai di majalah-majalah umumnya.

c. Kolaborasi antara jurnalis professional dengan non jurnalis yang memiliki kemampuan dalam materi/ bidang yang akan dibahas dalam artikel tersebut, sebagai bantuan dalam mengarahkan atau memeriksa keakuratan artikel. Terkadang professional non jurnalis ini bisa juga menjadi kontributor tunggal yang menghasilkan artikel tersebut. Ini juga bisa kita temui di media konvensional.

d. Bloghouse, sebuah website yang mengundang pembaca untuk ikut membaca.

e. Newsroom citizen 'transparency' blogs, merupakan blog yang disediakan untuk upaya transparansi organisasi sebuah media, dimana pembaca bisa memasukkan keluhan, kritikan, atau pujian atas pekerjaan media tsb.

f. Stand-alone citizen journalism site: melalui proses editing.

g. Stand-alone citizen journalism site: tanpa proses editing.

h. Stand-alone citizen-journalism website dengan tambahan edisi cetak. 
i. Hybrid: Pro + Citizen journalism. Suatu kerja organisasi media yang menggabungkan pekerjaan jurnalis professional dengan jurnalis warga. Disini ada peran para editor dalam menilai dan memilih berita yang akan diangkat ke halaman utama. Kontribusi berita tidak otomatis diterima sebagai sebuah berita, dan berita yang masuk masih tersaring lagi sebagai berita yang menjadi topik utama (berhak muncul di halaman pertama) atau bukan. Contohnya adalah ohmynews.com

j. Penggabungan antara jurnalis professional dan jurnalis warga dalam satu atap, dimana website membeli tulisan dari jurnalis professional dan menerima tulisan jurnalis warga.

k. Model wiki, dimana pembaca adalah juga editor. Setiap orang bisa menulis artikel, dan setiap orang bisa memberi tambahan atau komentar terhadap artikel yang terbit.

Pada penelitian ini, 11 lapisan CJ yang dikemukakan oleh Outing diatas akan dipakai sebagai salah satu titik pedoman analisa untuk mengetahui CJ yang menjadi obyek penelitian masuk pada area lapisan tidak.

Di negara asalnya AS, CJ berkembang dan diakui masyarakat karena pada beberapa kasus blog milik seorang netizen justru lebih mendapar perhatian dari pada media konvensional. Misalnya saja wonkette.com yang mendapat kunjungan 1 juta hit per hari melebihi audience harian nasional Pundit (Wood\& Smith, 2005, p. 133-134).

CJ sendiri memiliki keterkaitan dengan New Media Theory yang dikemukakan Denis McQuail (2000). Ia memperlihatkan adanya empat kategori media baru yang juga menjadi sifat dari CJ diantaranya, (1) Media komunikasi interpersonal, seperti telepon (yang semakin hari semakin bersifat mobile bahkan bisa terkoneksi internet) dan email, (2) Media interaktif, contohnya semua perangkat lunak yang ada di komputer dan video games, (3) Information seach media, contoh yang paling relevan adalah internet (www) yang merupakan sebuah perpustakaan dunia maya. 
Termasuk didalamnya adalah google.com, yahoo.com, msn.com. aol.com. Teknologi baru ini memingkinkan audience untuk aktif dan menjadi subyek sementara teknologi menjadi obyeknya, (4) Collective participatory media. Contohnya adalah penggunaan internet untuk sharing dan bertukar inforasi, ide, pengalaman dan mengambangkan hubungan berbasis internet. Disinilah letak obyek penelitian yaitu CJ berada. CJ bahkan telah meruntuhkan teori agenda seting, karena CJ menjadi penentu arah perkembangan isu, bahkan peran gatekeeping dan editing tidak lagi berada di editor (mainstream media) namun pada user.

Denis McQuail (2000, p. 127-128) juga memberikan 5 konsep pembeda antara media baru dengan media konvensional diantaranya: (1) Derajat interaktivitas, dimana interaksi dalam new media lebih fleksibel dan lebih tinggi dibanding media konvensional, (2) Derajat secial presence (keberadaan sosial) dimana media massa bersifat lebih personal, mengurangi ambiguitas. Pada penerapannya ,CJ sebagai media baru memungkinkan audience untuk bisa berhubungan secara personal dengan media dengan melakukan kontak langsung, (4) Derajat otonomi, dimana user dalam hal ini netizen memiliki kemmapuan untuk mengotrol isi dan penggunaan medianya sendiri dan menjadi sumber independen. Bagian ini menjadi bagian terpenting dalam sejarah keberadaan CJ, dimana warga bisa memiliki media sendiri dan diolah sendiri, (5) Derajat playfullness, kemampuan media menyediakan hiburan bagi para user, (6) Derajat privasi yang berhubungan dengan tepi isi yang dimiliki para pengguna media. Mereka bebas menampilkan apapun di media baru (internet) sehingga menghasilkan media yang unik (berbeda) dan personal.

Dalam new media theory, McQuail juga menunjukkan 6 perbedaan antara media lama dan media baru yaitu, (1) media lama konsepnya satu obyek berbicara pada banyak orang, sementara media baru bersifat decentralized yang artinya semua memiliki kesempatan berbicara kepada siapapun, (2) Media lama adalah one way communication, sementara media baru two way communication yang memungkinkan adanya 
feedback dari audiece, (3) media lama dibawah kontrol negara, sementara media baru diluar kontrol negara, bahkan bisa dinikmati siapapun yang ada didunia tanpa batasan negara, (4) media lama memproduksi lapisan sosial sementara media baru adalah memproduksi konsep demokratisasi, (5) media lama memfragmentasi audience sementara media baru meletakkan audience pada posisi yang sama, (6) media lama membentuk kebingungan sosial, sementara media baru berorientasi pada individu.

Dennis McQuail (2000) juga mengatakan bahwa media baru membuka kesempatan komunikasi yang lebih besar untuk demokrasi. Hal inilah yangmenjadi kunci konsep CJ yang pada dasarnya digunakan untuk komunikasi langsung antara citizen (warga) dengan negara yang selama ini dijembatani oleh mainstream media yang menyebut dirinya dari pilah ke-4 demokrasi. Lebih jauh CJ membuka forum terbuka bagi interaksi antar warga negara dan menjalankan fungsi advokasi dan watchdog yang selama ini didominasi oleh media konvensional. Fungsi watchdog memungkinkan warga untuk mengawasi kinerja pemerintah untuk memastikan bahwa pemerintah bekerja untuk kepentingan masyarakat luas. Hal itu senada juga dikemukakan oleh pencetus CJ yaitu Bowman and Willis yang mengatakan bahwa: "The intent of this participation is to provide independent, reliable, accurate, wide-ranging and relevant information that a democracy requires."

Raunda Hauben dalam presentasi di sebuah seminar tentang konferensi tahunan asosiasi peneliti internet bulan oktober 2008 mengemukakan bahwa internet memungkinkan netizen dalam CJ untuk menciptakan isi dan menset agenda media untuk didiskusikan. Dengan demikian netizen tidak hanya memiliki kemampuan menentukan isi namun juga mendesain bentuk forum yang mereka inginkan.

\section{Konsep Perlindungan Hukum}

Negara Indonesia adalah negara berdasarkan atas hukum dan setiap warga negara berhak untuk mendapat perlindungan hukum. Produk hukum dibuat untuk melindungi kepentingan masyarakat, dan juga menjadi 
kepentingan pelaku tindak pidana agar tidak diperlakukan secara sewenang-wenang oleh aparat penegak hukum.

Pada kenyataannya segolongan pihak tertentu justru melakukan tindakan yang melampaui kewenangan aparat penegak hukum. Cara-cara kekerasan atau anarki yang dilakukan oleh segolongan pihak tertentu yang merasa nama baiknya dirugikan oleh pemberitaan media, baik itu yang dilakukan secara terselubung, seperti terror melalui pesan singkat service message system (SMS), surat kaleng, ataupun teror melalui telepon, maupun ancaman yang dilakukan dengan terang-terangan seperti perusakan kantor media bersangkutan hingga mengakibatkan hilangnya nyawa seseorang, atau ancaman yang dilakukan dengan kata-kata secara langsung, sangat tidak dapat dibenarkan.

Saat ini terdapat pergeseran tindak kekerasan terhadap wartawan di sejumlah kota. Menurut Hasto Atmojo, wakil ketua Tim Pemantau Kekerasan Terhadap Wartawan, menyatakan bahwa tindak kekerasan terhadap wartawan pada masa

Berbicara mengenai perlindungan hukum tentu tidak terlepas dari konteks aparat penegak hukum. Fenomena yang paling tragis adalah ketika kita melihat anggota kepolisian, yang seharusnya menjadi pelindung pihak korban pada saat terjadi tindakan kekerasan tersebut, malah justru memilih untuk berdiam diri dan tidak melakukan perlindungan apapun bagi korban. Hal ini tidak hanya terjadi untuk tindak pidana kekerasan terhadap wartawan, namun juga sering terjadi pada beberapa tindak pidana lainnya.

Hak wartawan untuk mendapat perlindungan dari pemerintah diatur dalam ketentuan Pasal 28D ayat (1), Pasal 28F, Pasal 28G dan Pasal 28J ayat (2) UUD 1945 amandemen ke-4 belum terwujud maksimal. Pasal 28D ayat (1) berbunyi: "Setiap orang berhak atas pengakuan, jaminan, perlindungan, dan kepastian hukum yang adil serta perlakuan yang sama di hadapan umum" Pasal 28F: "Setiap orang berhak untuk berkomunikasi dan memperoleh informasi untuk mengembangkan pribadi dan lingkungan sosialnya, serta berhak untuk mencari, memperoleh, memiliki, 
menyimpan, mengolah dan menyampaikan informasi dengan menggunakan segala jenis saluran yang tersedia" Pasal 28 G: "Setiap orang berhak atas perlindungan diri pribadi, keluarga, kehormatan, martabat dan harta benda yang dibawah kekuasaannya, serta berhak atas rasa aman dan perlindungan dari ancaman ketakutan untuk berbuat atau tidak berbuat sesuatu yang merupakan hak asasi"

Terhadap prinsip-prinsip di atas yang merupakan sebagian dari 15 (lima belas) prinsip hak asasi manusia yang terkandung dalam UUD 1945 Amandemen ke-4, diartikan bahwa Negara telah menegaskan adanya komitmen Negara terhadap hak asasi manusia, namun komitmen tersebut belum mencerminkan keadaan yang sesungguhnya mengenai perlindungan dan pelaksanaan yang baik dari hak asasi manusia. Lebih lanjut Pasal 28J menyatakan: "Dalam menjalankan hak dan kebebasannya, setiap orang wajib tunduk kepada pembatasan yang ditetapkan dengan undangundangdengan maksud semata-mata untuk menjamin pngakuan serta penghormatan hak dan kebebasan orang lain dan untuk memenuhi tuntutan yang adil sesuai dengan pertimbangan moral, nilai-nilai agama, keamanan, dan ketertiban umum dalam suatu masyarakat demokratis" Terkait dengan Pasal 28J UUD 1945 Amandemen ke-4, dinyatakan bahwa setiap orang wajib tunduk terhadap suatu pembatasan yang ditetapkan dengan undangundang, sebagaimana dikutip.Dengan demikian, batas ini mempunyai nilai perlindungan baik bagi yang menyatakan pendapat, maupun bagi kutipan bagi pihak yang menjadi sasaran, obyek atau korban dari pernyataan tersebut. Batas tersebut akan mengingatkan warga negara sejauh mana ia dapat melaksanakan haknya dan tanggungjawab bilamana batas haknya ia lampaui atau dalam pelaksanaan hak tersebut ia telah melanggar atau disangka melanggar hak orang lain. Selanjutnya dikatakan:

"Dalam persoalan yang berhubungan dengan kebebasan pers maka tidak ada yang dinamakan dengan kebebasan yang mutlak. Kebebasan yang dimiliki oleh seseorang akan terhenti apabila melanggar kebebasan orang lain atau kepentingan umum. Dalam persoalan kemerdekaan menyatakan pendapat dengan adanya batas dalam hukum bentuk ini diharapkan orang: pertama, menjadi tidak 
sewenang-wenang dalam menyatakan pendapat atau menentukandirinya tidak melampaui batas dalam menyatakan pendapat; kedua, tidak secara sepihak dan juga tidak secara sewenang-wenang untuk menyatakan bahwa dirinya adalah pihak yang menjadi korban dari pernyataan pendapat; dan ketiga, tidak ada kesewenang-wenangan dalam bertindak dan menindak bilamana memang telah terjadi pelanggaran terhadap kemerdekaan pihak lain karena pelaksanaan dari kemerdekaan menyatakan pendapat itu...Dengan demikian hukumlah yang akan memberikan kriteria atau batas-batas tersebut, tidak diserahkan kepada para pihak untuk menentukan sendiri-sendiri.kalau hukum sudah hadir di dalam hukum tersebut terkandung akibat hukum jikalau dilanggar, maka di sinilah kemerdekaan menyatakan pendapat sebagian dari hak asasi manusia bertemu dengan pasangan abadinya yaitu kewajiban asasi manusia."

Penulis menyetujui pandangan tersebut di atas. Dalam pandangan penulis, apabila dikaitkan dengan kebebasan pers yang bertanggungjawab, maka untuk mencegah pers yang kebablasan, pers wajib tunduk terhadap ketentuan hukum, yang ditunjukkan untuk mencegah pelanggaran terhadap pemberitaan yang telah diatur dalam Pasal 5 ayat 1 UU Pers yaitu tentang peristiwa dan opini yang menghormati norma-norma agama dan rasa kesusilaan masyarakat serta asas praduga tak bersalah. Kemudian untuk masalah perlindungan hukum juga diatur dalam Pasal 3 ayat (2) dan Pasal 5 ayat (1) Undang-undang No. 39 Tahun 1999 tentang HAM (UU No. 39/1999) dan Pasal 4 UU Pers sebagai berikut : Pasal 3 ayat (2) UU No. 39/1999 : "Setiap orang berhak atas pengakuan,jaminan, perlindungan dan perlakuan hukum yang adil serta mendapat kepastian hukum dan perlakuan yang sama di depan hukum". Pasal 5 ayat (1) UU No. 39/1999 :"Setiap orang diakui sebagai manusia pribadi yang berhak menuntut dan memperoleh perlakuan serta perlindungan yang sama sesuai dengan martabat kemanusiaannya di depan hukum" .

Pasal 4 ayat (1) Undang-Undang Pers berbunyi :" Kemerdekaan pers dijamin sebagai hak asasi warga negara". Selanjutnya ayat (2) berbunyi : "Terhadap pers nasional tidak dikenakan penyensoran, pembredelan, atau pelarangan penyiaran". Dalam hal hak ingkar wartawan 
(hak tolak wartawan untuk menolak memberikan kesaksian dalam persidangan), saat ini masih menjadi perdebatan. Menurut Oemar Seno Adji, baik yurisprudensi maupun perundang-undangan belum dapat memberikan ketegasan tentang keadaan wartawan dapat membebaskan diri dari kewajiban untuk memberikan keterangan kesaksian. Sebagian kalangan ada yang mengakui hak ingkar tersebut, dan sebagian kalangan tidak mengakui, serta ada pula yang menyerahkannya kepada hakim. Di negara Norwegia, hak ingkar ini bukan bersifat absolut, karena hakim diberikan kewenangan dalam hal untuk memutuskan apakah redaktur (penerbit) dapat menjadi saksi.

\section{Perlindungan Hukum Bagi Jurnalisme Warga}

Perkembangan teknologi informasi ibarat banjir bandang. Iya kalau bisa dibendung, lha ini tak bisa dibendung. Karena membendungnya hampir bisa dikatakan membunuh ilmu pengetahuan. Maka kebebasan informasi pun tak hanya bisa dirayakan dengan mengobrak-abrik konten. Lebih dari itu, kini kita merayakan begitu banyaknya saluran informasi. Begitu ragamnya cara menikmati informasi.

Setelah berpuluh-puluh tahun media cetak dan elektronik mendominasi. Satu saluran baru hadir dengan kedigdayaannya menembus ruang dan waktu yakni media online/internet. Kehadirannya sempat membuat ketar-ketir media cetak. Bukan hanya sempat, sampai kini pun media cetak masih ketar-ketir. Buktinya, tidak sedikit media cetak yang mulai meng-online-kan informasi yang mereka punya.

Dibanding pendahulunya, internet punya logika yang jauh berbeda. Hanya kalangan berduit yang mampu memproduksi media cetak. Begitu pula media elektronik. Tentunya hal yang semacam itu tidak berlaku di dunia online. Siapapun, tak peduli kaya atau miskin bisa bermedia. Asal ponsel atau komputernya bisa terhubung dengan internet maka ia bisa menyebarkan informasi ke seluruh jagad dunia.

Inilah era citizen jurnalism alias jurnalisme warga. Era yang memungkinkan setiap orang melakukan kerja-kerja jurnalistik dengan 
begitu mudahnya. Tinggal memotret, mengetik lalu upload dan mendunia. Maka setiap orang kini bisa menjadi wartawan.

Merujuk pada Undang-Undang Nomor 40 Tahun 1999 tentang Pers, didefinisikan bahwa wartawan adalah orang yang secara teratur melaksanakan kegiatan jurnalistik. Sedang kegiatan jurnalistik meliputi mencari, memperoleh, memiliki, menyimpan, mengolah, dan menyampaikan informasi baik dalam bentuk tulisan, suara, gambar, suara dan gambar serta data dan grafik maupun dalam bentuk lainnya dengan menggunakan media cetak, media elektronik, dan segala jenis saluran yang tersedia.

Mencermati definisi yang termuat dalam UU tersebut cukup meyakinkan bila citizen jurnalism adalah juga wartawan. Hanya saja satu pertanyaan mengganjal di benak. Apakah para citizen jurnalism ini juga mendapat perlindungan hukum macam wartawan pada umumnya? Sebab, melongok UU pers, khususnya pasal 8 disebutkan dalam menjalankan profesinya wartawan mendapat perlindungan hukum. Nah, apakah ini berlaku juga untuk para jurnalis warga.

UU Pers belum menjelaskan secara gamblang perihal citizen jurnalism ini. Padahal, fenomena citizen jurnalism kini marak. Silahkan buktikan, googling dengan mengetik key word jurnalis warga maka bisa dijumpai begitu banyak situs yang menampung kabar berita dari warga. Perlu ada ketentuan soal jurnalisme warga ini, karena bagaimanapun mereka yang sedang ber-citizen jurnalism ini adalah sedang melancarkan hak asasi mereka terkait informasi.

Berkembangnya jurnalisme online di Indonesia saat ini, dapat semakin menguatkan perkembangan citizen journalism. Dalam citizen journalism, masyarakat dapat membahas hal-hal yang tengah 'hangat' dalam masyarakat dalam segala aspek. Kini, minat masyarakat pada jurnalisme online terus meningkat. Jurnalisme online telah menjadi prioritas bagi masyarakat dalam mengakses informasi. Hal ini menyebabkan perkembangan dari citizen journalism akan terus meningkat. 
Fungsi dari jurnalisme online tidak hanya sebagai alat uintuk mendapat informasi, tetapi juga dapat sebagai pertukaran informasi para penggunanya, dimana para penggunanya bersifat heterogen. Hal ini dapat menjadi kekuatan dari citizen journalism.

Selain kekuatan yang dimiliki citizen journalism, dimana citizen journalism memungkinkan masyarakat dapat bertukar informasi mengenai suatu hal yang dapat membuat masyarakat semakin terbuka wawasannya, hal inilah merupakan salah satu bentuk demokrasi dalam hal mengeluarkan pendapat secara sehat dan tidak melanggar hukum. Citizen journalism juga memiliki kendala yang sulit dihindari yang dapat menjadi tantangan bagi keberadaan citizen journalism ke depan. Sifat citizen journalism yang memungkinkan semua pengakses internet dapat memasukkan informasi yang ia miliki melalui internet, dapat menyebabkan keadaan semacam 'penyalahgunaan wewenang' oleh pengakses. Tidak adanya batasan yang jelas mengenai apa yang boleh dan tidak boleh dimasukkan dalam internet telah membuat situs dan blog memuat informasi yang tidak seharusnya.

Selain tidak adanya batas yang jelas, hal lain yang dapat menjadi tantangan dalam citizen journalism adalah masyarakat atau orang-orang yang memasukkan informasi melalui internet tidak harus melalui pendidikan jurnalisme terlebih dahulu. Dalam citizen journalism, semua orang dapat menjadi wartawan. Oleh sebab itu, terkadang berita yang dimuat terkadang tidak sesuai dengan aturan penulisan berita atau etika jurnalisme yang ada.

Mengacu pada Deklarasi Hak Asasi Manusia PBB, pasal 19 yang menyatakan bahwa Setiap orang berhak atas kebebasan memiliki dan menyatakan pendapat; hak ini meliputi pendapat tanpa campur tangan dan untuk mencari, menerima dan ikut ambil bagian dalam kegiatan informasi dan gagasan melalui setiap macam media dan tanpa memandang batas wilayah. Dengan demikian setiap warga masyarakat secara normatif mempunyai hak berpendapat terhadap apa yang terjadi di lingkungan 
sekitarnya, dan sekaligus juga mempunyai hak untuk mendapatkan kesempatan yang sama untuk mengetahui apa yang terjadi. Hak ini dijamin secara universal, sifat universal dari norma ini memberikan urutan dari hak-hak manusia, dimulai dari yang bersifat asasi yang melekat pada diri manusia, disusul hak manusia dalam lingkup keluarga, kemudian dalam lingkup suku (etnis), baru dalam lingkup nasional.

Berkaitan dengan kebebasan tersebut, hubungannya dengan pers, dimana terjadi monopoli proses penyampaian informasi, sehingga yang terjadi adalah monopoli dalam alam pikiran dan pendapat dalam masyarakat. Kekuasaan monopoli ini dapat bersumber dari birokrasi negara, kekuatan modal, ataupun komunalisme masyarakat. Dalam kasus ini terjadi pemaksaan kepentingan ke dalam informasi, disinilah ditemukan bias kebebasan pers. Seharusnya kebebasan harus diletakkkan dalam definisi bebas dari kekuatan luar dan sekaligus bebas untuk menggunakan haknya.

Media massa khususnya media pers sebenarnya berfungsi sebagai person pada tataran institusional, yaitu dalam keberadaannya sebagai bagian (warga) dari suatu institusi sosial, politik, ekonomi dan kultural. Apabila dibuatkan suatu urutan komunikasi bagi seseorang, hirarkinya dimulai dari komunikasi intrapribadi-antarpribadi-intrakelompokantarkelompok-institusi-media massa. Jadi fungsi pers dalam menyediakan informasi tidak terlepas dari keberadaannya sebagai institusi sosial, yang dilekatkan dengan fungsi yang harus dijalankannya dalam sisitem sosial. Keberadaan pers dalam sisitem sosial ini melahirkan pengelolaan media sebagai aktor sosial. Pada titik inilah lahir informasi yang objektif (faktual) dan subjektif (rekayasa). Masyarakat dlam hal ini lebih banyak yang menikmati informasi hiburan news, dorongan ini membentuk pembiasan dinamika sosial warga terhadap kehidupan luar dirinya, sehingga kebutuhan akan informasinya lebih terhormat. Akhirnya peran sosialnya dijalankan tanpa dinamika empiris objektif. Kekuasaan yang hegemonik pada dasarnya menyebabkan seseorang tidak memerlukan 
informasi faktual, sebab keputusan-keputusan dapat dijalankan secara instruksional bersifat paksaan.

Sifat hegemonik dan korporatis ini selanjutnya melahirkan politik pemberitaan media. Informasi dikemas sebagai strategi media dalam meliput peristiwa, memilih, dan menampilkan fakta serta dengan cara apa fakta itu disajikan, yang pada akhirnya merekonstruksi peristiwa. Disinilah lahir politik pemaknaan. Pers tidak lagi mereproduksi peristiwa, melainkan menentukan realitas melalui pemaknaan dengan bahasa yang terpilih. "Pemecatan" diganti dengan "pemutusan hubungan kerja", "penggarap liar" untuk mendefinisikan petani penggarap bukan pada lahannya, "relokasi" untuk pemindahan paksa sebuah komunitas warga. Pers terpola untuk mencari sumber statement dari penguasa. Sementara yang ditonjolkan tindakan merusak dari kaum marjinal yang sebenarnya yang dirugikan. Ketika buruh pabrik melakukan demonstrasi menuntut hak, yang disorot kamera adalah kemacetan yang diakibatkan oleh demonstrasi tersebut. Sementara statament dikutip dari pemilik pabrik yang rugi sekian ratus juta dalam sehari akibat demonstrasi tersebut.

Pola semacam ini pada akhirnya membentuk opini, bahwa selalu saja warga yang bersalah, penguasa yang benar. Padahal fakta yang sebenarnya tidak demikian. Tetapi itulah yang telah terformat selama ini. Karena media massa berada dalam hegemoni sebagai institusi pers yang mengemban politik pemberitaan. Seharusnya media mempunyai peran yang besar dalam mendefinisikan realitas. Disinilah kekuatan Citizen Journalism bisa mengambil peran. Dengan independensinya seharusnya jurnalisme warga dapat menyuarakan fakta yang sesungguhnya Buruh yang berdemonstrasi itu dapat menyampaikan informasi yang sesungguhnya dari apa yang mereka perjuangkan. Langsung dari dirinya sendiri sebagai sumber. Dan ini dapat menjadi counterattackbagi media massa yang hanya berpihak pada kepentingan dominan. Dengan format yang sama, seorang warga RT dapat memberitakan kritikannya terhadap Ketua RT nya yang selama ini tidak mendapat tanggapan. Dan jika pun dia 
dapat mengakses media, media bukanlah saluran yang bebas, ia juga subjek yang mengkonstruksi realitas, lengkap dengan pandangan, bias, dan pemihakannya.

\section{PENUTUP}

\section{Kesimpulan}

Berkembangnya jurnalisme online di Indonesia saat ini, dapat semakin menguatkan perkembangan citizen journalism. Dalam citizen journalism, masyarakat dapat membahas hal-hal yang tengah 'hangat' dalam masyarakat dalam segala aspek. Kini, minat masyarakat pada jurnalisme online terus meningkat. Jurnalisme online telah menjadi prioritas bagi masyarakat dalam mengakses informasi. Hal ini menyebabkan perkembangan dari citizen journalism akan terus meningkat. Fungsi dari jurnalisme online tidak hanya sebagai alat uintuk mendapat informasi, tetapi juga dapat sebagai pertukaran informasi para penggunanya, dimana para penggunanya bersifat heterogen.

Selain kekuatan yang dimiliki citizen journalism, dimana citizen journalism memungkinkan masyarakat dapat bertukar informasi mengenai suatu hal yang dapat membuat masyarakat semakin terbuka wawasannya, hal inilah merupakan salah satu bentuk demokrasi dalam hal mengeluarkan pendapat secara sehat dan tidak melanggar hukum.citizen journalism juga memiliki kendala yang sulit dihindari yang dapat menjadi tantangan bagi keberadaan citizen journalism ke depan. Sifat citizen journalism yang memungkinkan semua pengakses internet dapat memasukkan informasi yang ia miliki melalui internet, dapat menyebabkan keadaan semacam 'penyalahgunaan wewenang' oleh pengakses. Tidak adanya batasan yang jelas mengenai apa yang boleh dan tidak boleh dimasukkan dalam internet telah membuat situs dan blog memuat informasi yang tidak seharusnya. 


\section{DAFTAR PUSTAKA}

Arif Swa, Pertarungan Citizen Journalism, Kompasiana, 2010

J.Irwin, Citizen Journalism: Media Massa yang Paling Jujur, Wikimu, 2009

Didit Adiputro, Citizen Journalism Wujud Dari Demokrasi Total, Jakarta, Perspektif Online, 2009.

Sabjan Badio, Revolusi itu Bernama Citizen Journalism. Jakarta, 2009

Ummuyati, Dinamisasi Berita Pada Website Pemerintah dengan Pendekatan Citizen Journalism. Jakarta, 2010

Anton Muhajir, Berbagi Komitmen Untuk Citizen Journalis, Jakarta, 2009

Muh. Asdar Yusuf, Citizen Journalist dan Perubahan, Jakarta, 2010

Moch. Kurniawan, Jurnalisme Warga di Indonesia dan Tantangannya, Jakarta, 2007

JD Lasica, Online Journal's Review, 2003

Admin, rumahkiri.net, 2008

Dirgahayu, Jurnal Observasi, 2007

Aurelia dkk, di Blogdetik, 2008

Yenti dkk, di Blogdetik, 2008 